\title{
Virulent Staphylococcus lugdunensis with limited genetic diversity in hidradenitis suppurativa lesions
}

Ardon, C.B; Prens, E.P.; Tkadlec , J.; Fuursted, Kurt; Abourayale, Sali; Jemec, G.B.E.; Jenssen, Håvard

Published in:

Journal of the European Academy of Dermatology and Venereology

DOI:

$10.1111 / j d v .15523$

Publication date:

2019

Document Version

Peer reviewed version

Citation for published version (APA):

Ardon, C. B., Prens, E. P., Tkadlec, J., Fuursted, K., Abourayale, S., Jemec, G. B. E., \& Jenssen, H. (2019).

Virulent Staphylococcus lugdunensis with limited genetic diversity in hidradenitis suppurativa lesions. Journal of the European Academy of Dermatology and Venereology, 33(6), e248-e250. https://doi.org/10.1111/jdv.15523

\section{General rights}

Copyright and moral rights for the publications made accessible in the public portal are retained by the authors and/or other copyright owners and it is a condition of accessing publications that users recognise and abide by the legal requirements associated with these rights.

- Users may download and print one copy of any publication from the public portal for the purpose of private study or research.

- You may not further distribute the material or use it for any profit-making activity or commercial gain.

- You may freely distribute the URL identifying the publication in the public portal.

Take down policy

If you believe that this document breaches copyright please contact rucforsk@kb.dk providing details, and we will remove access to the work immediately and investigate your claim. 
MS. CHRISTINE B. ARDON (Orcid ID : 0000-0002-2303-4604)

Article type : Letter to Editor

Virulent Staphylococcus lugdunensis with limited genetic diversity in hidradenitis suppurativa lesions

C.B. Ardon ${ }^{1,2^{*}}$, E.P. Prens ${ }^{1}$, J. Tkadlec ${ }^{3}$, K. Fuursted ${ }^{4}$, S. Abourayale ${ }^{2}$, G.B.E. Jemec $^{5}, \mathrm{H}$. Jenssen $^{2 *}$

Affiliations:

${ }^{1}$ Dept. of Dermatology, Erasmus MC, University Medical Center Rotterdam, Rotterdam, the Netherlands.

${ }^{2}$ Dept. of Science and Environment, Roskilde University, Roskilde, Denmark

${ }^{3}$ Dept. of Medical Microbiology, $2^{\text {nd }}$ Faculty of Medicine, Charles University and Motol University Hospital, Prague, Czech Republic.

${ }^{4}$ Dept. of Microbiology and Infection Control, Staten Serum Institute, Copenhagen, Denmark.

${ }^{5}$ Dept. of Dermatology, University Hospital Zealand, Roskilde, Denmark.

\section{Correspondence:}

Christine B. Ardon, Department of Dermatology, Erasmus MC, Dr. Molewaterplein 40, 3015 GD, Rotterdam, the Netherlands.

Email: c.ardon@erasmusmc.nl, telephone number: +31 1017040110

Håvard Jenssen, Department of Science and Environment, Roskilde University, Universitetsvej 1, DK-4000, Roskilde, Denmark.

Email: jenssen@ruc.dk, telephone number: +45 46742877

This article has been accepted for publication and undergone full peer review but has not been through the copyediting, typesetting, pagination and proofreading process, which may lead to differences between this version and the Version of Record. Please cite this article as doi: $10.1111 / j d v .15523$

This article is protected by copyright. All rights reserved. 
Conflict of interest: the authors have no conflicts of interest to declare

Funding: Funding has been provided by Roskilde University doctoral school program for Basic and Clinical Microbiology and Roskilde Hospital.

\section{To the editor,}

Hidradenitis suppurativa (HS) is an inflammatory skin disease characterized by recurring painful, deep-seated inflammatory nodules, abscesses, sinus tracts, and scarring in the intertriginous areas. ${ }^{1}$ Bacteria may be involved in the pathogenesis of HS via follicular dysbiosis in the initial stages, and via biofilm in chronic sinus tracts. ${ }^{2}$ Staphylococcus lugdunensis, a coagulase-negative staphylococcus (CNS), has been cultured from hidradenitis suppurativa nodules and abscesses. This points towards a role of S. lugdunensis in the aggravation and secondary colonization of HS lesions. ${ }^{3,4} \mathrm{~S}$. lugdunensis has also been associated with biofilm-driven infections in different tissues. ${ }^{5}$ Therefore, we compared the in vitro growth, antibiotic susceptibility and biofilm-forming capabilities of $S$. lugdunensis strains from HS lesions with those of healthy controls and a reference strain.

This study has been approved by the ethical board and the data protection agency of Denmark. Informed consent was obtained from all participants. The $S$. lugdunensis strains were cultured from punch biopsies and swabs from active HS lesions. The controls comprised two strains from one healthy participant and the ATCC 49576 control strain. All strains were typed as described previously. ${ }^{6}$ Rifampicin, tetracycline, clindamycin and doxycycline, commonly used to treat HS, were included in the experiments. Genetic relatedness of the S. lugdunensis strains was investigated with Pulsed-Field Gel Electrophoresis $(\mathrm{PFGE})^{7}$ and analysed using BioNumerics software (version 5.0). 
S. Iugdunensis was cultured in 12 out of 26 patients (46\%). All strains showed growth in liquid medium in vitro, however after 6 hours the HS lesional strains and the control strain grew faster than the two strains from a healthy individual (HS versus healthy $p<0.0354$; control versus healthy $p<0.0299$ ). All strains were strong biofilm producers, but the healthy strains produced less biofilm when compared to HS lesional strains and the control strain. Clindamycin resistance was observed in $41.6 \%$ of the strains (Table 1). Rifampicin was superior to clindamycin, doxycycline, and tetracycline in both growth-inhibition and biofilm eradication $(p<0.05$, Fig. 1). Five clusters of genetically closely related strains were identified, mostly in pairs. A high similarity was seen within the clusters especially for the two healthy strains.

The specific pathway by which bacteria are involved in the pathogenesis of HS needs further elucidation. Differences in the functional characteristics of $S$. lugdunensis strains from HS patients were identified in our study. The faster growth curves of the lesional HS and control strains than healthy strains, indicate a more pathogenic virulent status of the lesional S. lugdunensis strains. ${ }^{8}$ Nonetheless, the biofilm forming capacities were identical. The high clindamycin resistance rate of $41.6 \%$ has previously been reported in more than $10 \%$ of the S. lugdunensis strains. ${ }^{9}$ Doxycycline appeared particularly effective at inhibiting the growth of $S$. lugdunensis, which may suggest that doxycycline could be used in the management of HS when CNS are present.

All tested antibiotics significantly eradicated biofilm in the four tested strains. Interestingly, this also occurred in strain number 4 , which showed resistance against tetracycline, doxycycline and clindamycin. Resistance to clindamycin is mostly 
caused by a mutation whereby the receptor for the antibiotic is modified. ${ }^{10}$ Our findings in strain 4 imply that the efficacy of clindamycin in biofilm degradation is independent of its bactericidal activity. The close genetic relatedness of the strains, with five highly similar clusters, indicates that the number of specific strains that are involved in HS pathogenesis is limited.

A major strength of this study is the carefully optimized culture conditions for our experiments. A limitation is that by culturing the biopsies, and not using molecular bacterial sequencing such as $16 \mathrm{~S}$ ribosomal RNA techniques, we possibly missed some bacterial strains.

In conclusion, we show that $S$. lugdunensis strains were more frequently resistant to antibiotics used to treat HS, and showed an increased biofilm production. Based on our current findings, it is conceivable that these characteristics may foster HS disease activity. A larger sample size across different HS phenotypes and anatomical regions with bacterial genome sequencing is needed for a better picture of the role of $S$. lugdunensis in HS.

\section{Conflicts of interest}

None of the authors has any conflict of interest to declare.

This article is protected by copyright. All rights reserved. 


\section{References}

1. Jemec GB. Clinical practice. Hidradenitis suppurativa. N Engl J Med. 2012;366; 158-164.

2. Ring HC, Emtestam L. The Microbiology of Hidradenitis Suppurativa. Dermatol Clin. 2016;34; 29-35.

3. Guet-Revillet H, Coignard-Biehler H, Jais JP, Quesne G, Frapy E, Poiree S, et al. Bacterial pathogens associated with hidradenitis suppurativa, France. Emerg Infect Dis. 2014;20; 1990-1998.

4. Sartorius K, Killasli H, Oprica C, Sullivan A, Lapins J. Bacteriology of hidradenitis suppurativa exacerbations and deep tissue cultures obtained during carbon dioxide laser treatment. $\mathrm{Br} \mathrm{J}$ Dermatol. 2012;166; 879-883.

5. Frank KL, Del Pozo JL, Patel R. From clinical microbiology to infection pathogenesis: how daring to be different works for Staphylococcus lugdunensis. Clin Microbiol Rev. 2008;21; 111-133.

6. Ardon CB, Prens EP, Fuursted K, Ejaz RN, Shailes J, Jenssen H, et al. Biofilm production and antibiotic susceptibility of Staphylococcus epidermidis strains from Hidradenitis Suppurativa lesions. J Eur Acad Dermatol Venereol. 2018.

7. Chung $M$, de Lencastre H, Matthews P, Tomasz A, Adamsson I, Aires de Sousa M, et al. Molecular typing of methicillin-resistant Staphylococcus aureus by pulsed-field gel electrophoresis: comparison of results obtained in a multilaboratory effort using identical protocols and MRSA strains. Microb Drug Resist. 2000;6; 189-198.

8. Smirnova GV, Oktyabrsky ON. Relationship between Escherichia coli growth rate and bacterial susceptibility to ciprofloxacin. FEMS Microbiol Lett. 2018;365.

9. Hellbacher C, Tornqvist E, Soderquist B. Staphylococcus lugdunensis: clinical spectrum, antibiotic susceptibility, and phenotypic and genotypic patterns of 39 isolates. Clin Microbiol Infect. 2006;12; 43-49.

10. Leclercq R, Courvalin P. Bacterial resistance to macrolide, lincosamide, and streptogramin antibiotics by target modification. Antimicrob Agents Chemother. 1991;35; 1267-1272.

This article is protected by copyright. All rights reserved. 


\section{Legend for figure}

Figure 1. Eradication of bacterial biomass in preformed biofilms exposed to rifampicin $(0.0625 \mu \mathrm{g} / \mathrm{mL})$, tetracycline $(0.25 \mu \mathrm{g} / \mathrm{mL})$, clindamycin $(0.25 \mu \mathrm{g} / \mathrm{mL})$ and doxycycline $(0.125 \mu \mathrm{g} / \mathrm{mL})$ for 24 hours. The graphs are showing HS strain number 4 (a), HS strain number 5 (b), the healthy control strains (c) and the laboratory control strain (d). The graphs are normalized to the growth controls (no stimuli added), which is depicted as $100 \%$ of biofilm formation. Statistical significance is indicated with asterisks * $p<0.05$, (GraphPad Prism USA).

This article is protected by copyright. All rights reserved. 


\section{Table}

Table 1. Antimicrobial susceptibility and biofilm production pattern for all strains.

\begin{tabular}{|c|c|c|c|c|c|c|}
\hline \multirow[b]{2}{*}{ S. lugdunesis strains } & \multicolumn{4}{|c|}{$\mathrm{MIC}(\mu \mathrm{g} / \mathrm{mL})$} & \multirow[b]{2}{*}{ Antibiotic use } & \multirow[b]{2}{*}{$\begin{array}{l}\text { Biofilm } \\
\text { production }\end{array}$} \\
\hline & Rif & Tet & Clinda & Doxy & & \\
\hline Strain 1 (biopsy) & 0.03 & 0.25 & $\geq 128$ & 0.13 & None & Strong \\
\hline Strain 2 (biopsy) & 0.06 & 0.25 & 0.50 & 0.13 & None & Strong \\
\hline Strain 3 (biopsy) & 0.03 & 0.25 & $\geq 128$ & 0.13 & None & Strong \\
\hline Strain 4 (biopsy) & 0.06 & $\underline{64}$ & $\geq 128$ & $\underline{4}$ & Clindamycin lotion & Strong \\
\hline Strain 5 (biopsy) & 0.06 & 0.13 & 0.50 & 0.13 & None & Strong \\
\hline Strain 6 (biopsy) & 0.03 & 0.25 & 0.25 & 0.13 & Clindamycin lotion & Strong \\
\hline Strain 7 (biopsy) & 0.06 & 0.13 & 0.25 & 0.25 & Unknown & Strong \\
\hline Strain 8 (biopsy) & 0.01 & 0.25 & $\geq 128$ & 0.13 & None & Strong \\
\hline Strain 9 (biopsy) & 0.03 & 0.50 & $\geq 128$ & 0.13 & Clindamycin lotion & Strong \\
\hline Strain 10 (swab) & 0.06 & 0.50 & 0.50 & 0.25 & None & Strong \\
\hline Strain 11 (swab) & 0.06 & 0.50 & 0.50 & 0.25 & None & Strong \\
\hline Strain 12 (swab) & 0.06 & 0.25 & 0.25 & 0.25 & None & Strong \\
\hline Healthy control (biopsy) & 0.06 & 0.25 & 0.25 & 0.13 & None & Strong \\
\hline Healthy control (swab) & 0.06 & 0.25 & 0.25 & 0.13 & None & Strong \\
\hline Laboratory control strain & 0.06 & 0.13 & 0.25 & 0.13 & None & Strong \\
\hline
\end{tabular}

Rif, rifampicin; Tet, tetracycline; Clinda, clindamycin; Doxy, doxycycline

Notes: Resistance is indicated in bold with an underlining. (a) received topical clindamycin treatment prior to collection the biopsies/swabs, while (b) has an unknown antibiotic treatment history.

This article is protected by copyright. All rights reserved. 
(a)

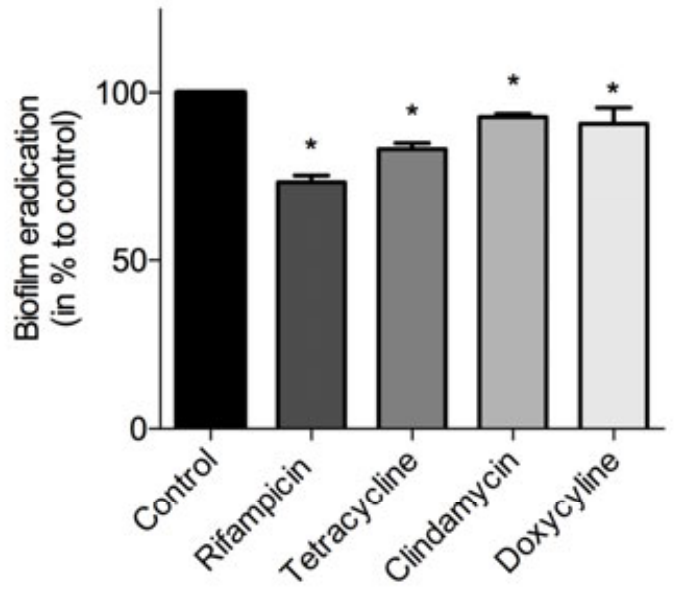

(c)

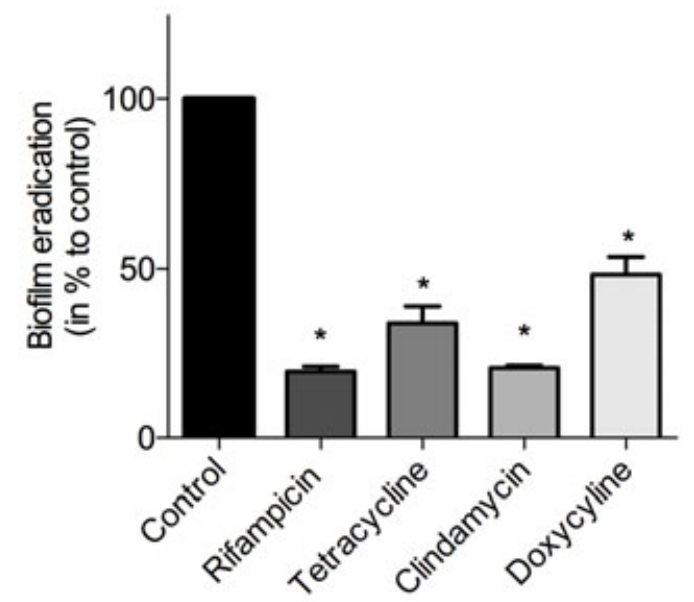

(b)

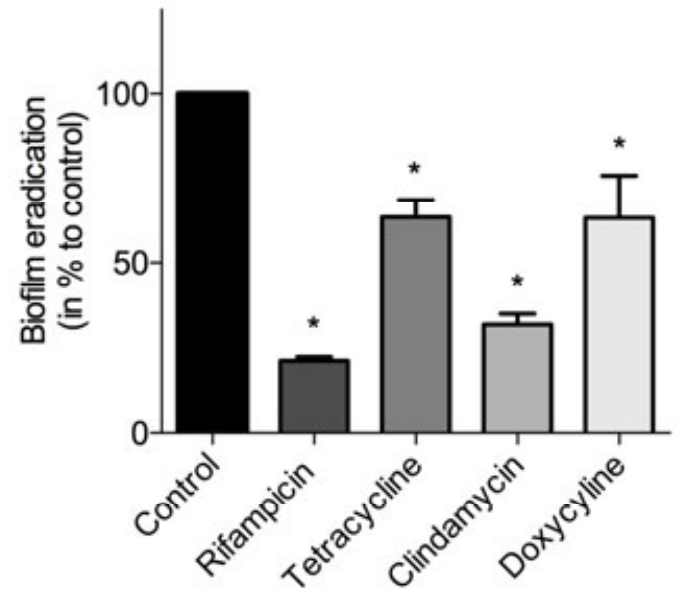

(d)

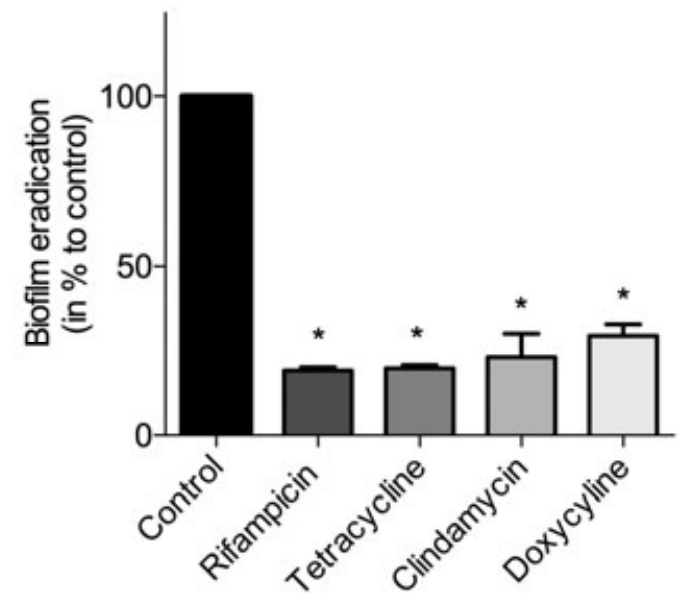

